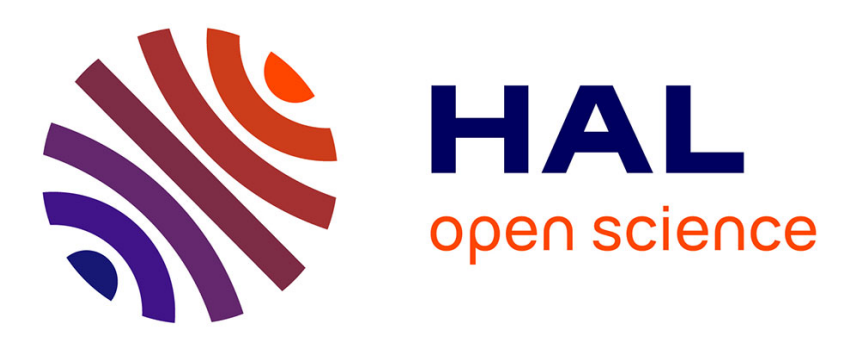

\title{
Effect of tidal flooding on metal distribution in pore waters of marsh sediments and its transport to water column (Tagus estuary, Portugal)
}

Juan Santos-Echeandía, Carlos Vale, Miguel Caetano, Patrícia Pereira, Ricardo Prego

\section{To cite this version:}

Juan Santos-Echeandía, Carlos Vale, Miguel Caetano, Patrícia Pereira, Ricardo Prego. Effect of tidal flooding on metal distribution in pore waters of marsh sediments and its transport to water column (Tagus estuary, Portugal). Marine Environmental Research, 2010, 70 (5), pp.358. 10.1016/j.marenvres.2010.07.003 . hal-00631692

\section{HAL Id: hal-00631692 \\ https://hal.science/hal-00631692}

Submitted on 13 Oct 2011

HAL is a multi-disciplinary open access archive for the deposit and dissemination of scientific research documents, whether they are published or not. The documents may come from teaching and research institutions in France or abroad, or from public or private research centers.
L'archive ouverte pluridisciplinaire HAL, est destinée au dépôt et à la diffusion de documents scientifiques de niveau recherche, publiés ou non, émanant des établissements d'enseignement et de recherche français ou étrangers, des laboratoires publics ou privés. 


\section{Accepted Manuscript}

Title: Effect of tidal flooding on metal distribution in pore waters of marsh sediments and its transport to water column (Tagus estuary, Portugal)

Authors: Juan Santos-Echeandía, Carlos Vale, Miguel Caetano, Patrícia Pereira, Ricardo Prego

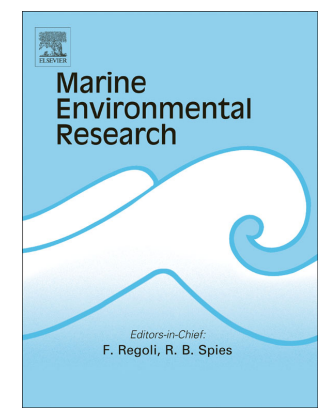

PII: S0141-1136(10)00112-1

DOI: 10.1016/j.marenvres.2010.07.003

Reference: MERE 3465

To appear in: Marine Environmental Research

Received Date: 1 June 2010

Revised Date: 16 July 2010

Accepted Date: 18 July 2010

Please cite this article as: Santos-Echeandía, J., Vale, C., Caetano, M., Pereira, P., Prego, R. Effect of tidal flooding on metal distribution in pore waters of marsh sediments and its transport to water column (Tagus estuary, Portugal), Marine Environmental Research (2010), doi: 10.1016/ j.marenvres.2010.07.003

This is a PDF file of an unedited manuscript that has been accepted for publication. As a service to our customers we are providing this early version of the manuscript. The manuscript will undergo copyediting, typesetting, and review of the resulting proof before it is published in its final form. Please note that during the production process errors may be discovered which could affect the content, and all legal disclaimers that apply to the journal pertain. 
1 Effect of tidal flooding on metal distribution in pore waters of marsh sediments and its transport to water column (Tagus estuary, Portugal)

Juan Santos-Echeandía ${ }^{a, b_{\star}}$, Carlos Vale $^{b}$, Miguel Caetano ${ }^{b}$, Patrícia Pereira ${ }^{b}$ and Ricardo Prego ${ }^{a}$

aMarine Reseach Institute (CSIC), Department of Oceanography, Eduardo Cabello 6, 36208, Vigo, Spain

bIPIMAR, National Institute of Biological Resources, Avenida Brasília 1446-006, Lisboa, Portugal

Carlos Vale: cvale@ipimar.pt

9 Miguel Caetano: mcaetano@ipimar.pt

10 Patricia Pereira: patbio@ipimar.pt

11 Ricardo Prego: prego@iim.csic.es

*Corresponding author: Juan Santos Echeandía

\section{Abstract}

Sediment cores and flooding water were collected at 0, 5, 10 and 50 minutes of tidal inundation in two sites of the Rosário salt marsh located in the proximity of a heavy industrialised zone of Tagus estuary colonised by pure stands of Spartina maritima (low marsh) and Sarcocornia fruticosa (high marsh). The cores were sliced in 5-cm layers and sediment solids, pore water, and belowground biomass were separated in order to measure $\mathrm{Fe}, \mathrm{Mn}, \mathrm{Zn}, \mathrm{Cu}, \mathrm{Pb}$ and $\mathrm{Cd}$. The pore waters and sediments colonised by S. fruticosa, as well as belowground biomass presented high concentrations of $\mathrm{Zn}, \mathrm{Cu}, \mathrm{Pb}$ and $\mathrm{Cd}$. Belowground biomass exceeded in one order of magnitude the metal levels in sediments. Abundant belowground biomass and small dimension of $S$. fruticosa roots facilitates the root-sediment interactions and presumably the metal retention in the higher marsh. The novelty of this work is the result of tidal inundation on pore water concentrations of metals in salt marsh sediments and their exportation to the water column. Concentrations in pore waters varied at minute scales, but 50 minutes after inundation levels were comparable to the initial values. The metal levels in flooding water increased abruptly during the first 10 to 20 minutes of inundation. The concentration peaks ( $\mathrm{Fe}=60 \mu \mathrm{M}, \mathrm{Mn}=7.5 \mu \mathrm{M}, \mathrm{Zn}=1.7 \mu \mathrm{M}$, $\mathrm{Cu}=550 \mathrm{nM}, \mathrm{Pb}=100 \mathrm{nM}, \mathrm{Cd}=1.7 \mathrm{nM}$ ) reached one to two orders of magnitude above the values found in subsequent periods of inundation. The advective transports during the 50 -min inundation during two daily pulses of inundation were: $\mathrm{Fe}$ (9520 and 1640), $\mathrm{Mn}$ (24), $\mathrm{Zn}$ (220 and 82), $\mathrm{Cu}$ (74 and 16), $\mathrm{Pb}$ (13 and 15) and $\mathrm{Cd}(0.3$ and 0.08$)$ for $S$. maritima and $S$. fruticosa, respectively. These quantities exceeded 3 to 4 orders of magnitude of the corresponding predicted diffusive fluxes (Fick $1^{\text {st }}$ law) on a daily basis. This work emphasizes the importance of tidal flooding over salt marsh sediments to the metal exportation to the water column. 
44 Keywords: Salt marsh; metals; pore-waters; Tagus estuary; advective; diffusive; fluxes; tidal flooding.

45

46

47

48

49

50

51

52

53

54

55

56

57

58

59

60

61

62

63

64

65

66

67

68

69

70

71

72

73

74

75

76

77

78

79

80

81

82

83

84

85

86

\section{Introduction}

The post-mobilisation of deposited iron, manganese and trace elements has been extensively studied in deep and coastal sediments (e.g., review Sundby, 2006). On the basis of vertical properties of sediment pore water ( $\mathrm{pH}$, redox potential, dissolved oxygen, sulphur compounds, nutrients and metals) and of metal concentrations in solid sediments, it was proposed a sequence of reactions for the oxidation of the labile sedimentary organic matter that reaches the sediment surface (Aller, 1977; Froelich et al., 1979). Oxygen diffused from the water column into the upper sediment layer is the most favourable oxidant, and as concentration decreases with the depth other oxidants are consumed to degrade the organic matter. Reactions of similar free energy like nitrate and manganese oxide may overlap, (Burdige, 1993; van Capellen and Yang, 1996). The chemical zonation in the upper sediments is characterised by gradients with the depth, concentrations in pore waters exceeding largely the levels in overlying water. These differences result in diffusive fluxes of solutes from sediments to water column (Berner, 1980). The presence and activity of macroinvertebrates, causing perturbation and irrigation in the upper sediments, enhances the sediment-water exchanges of solutes (Brune et al., 2000). The pore waters of inter-tidal permeable sediments are renewed as tidal water floods the area causing exports of solutes by pulses (Falcão and Vale, 1990; Caetano et al, 2007).

The salt marsh sediments have specificities with relevance to early diagenesis and sediment-water exchanges such as: deliver of oxygen into subsurface layers of sediments by plant roots (Clothier and Green, 1997; Caetano and Vale, 2002); supply of organic matter as roots dye (Caçador et al, 2004; Pereira et al, 2007); presence of a mosaic of small channels in the upper sediments where tidal water excurses during flooding. Works have reported two situations: anaerobic conditions in the rooting sediments, meaning that delivered oxygen was insufficient to oxidise the large amount of degradable organic matter (Haines and Dunn, 1985; Mendelssohn et al., 1995; Sundby et al., 2003); oxic to suboxic conditions suggesting an excess of oxygen supplied to the sediment for the requirements. Various studies have been focused on the influence of root-sediment interactions on sediment chemistry (Sundby et al., 2003; 2005; Taillefert et al., 2007; Koretsky et al., 2008a,b) and response of plants (Windham et al., 2001; Jacob and Otte, 2003; Weis and Weis, 2004; Caetano et al., 2007; 2008). However, sediment-water exchanges in salt marsh are poorly documented (Taillefert et al., 2007).

Several studies showed that Tagus salt marshes, including Rosário, incorporate large quantities of anthropogenic metals into the colonised sediments (e.g. Caçador et al., 1993; 1996; 2000; Sundby et al., 1998; Caetano et al., 2007). Retention of contaminated particles from the anthropogenic sources (Vale, 1990) and root-sediment interactions appear to contribute to the metal enrichment of colonised sediments and belowground biomass (Caçador et al., 1993; 1996). Recent studies in Rosário have shown that as root dye the accumulated and sorbed metals are redistributed in the sediments (Pereira et al, 2007). Few works have been focused on Tagus marshes pore waters. Reboreda and Caçador (2007) have reported high concentrations of trace metals in bulk pore waters of rooting sediment. By using an amalgam voltammetric microelectrode Sundby et al. $(2003 ; 2005)$ proved that dissolved oxygen, $\mathrm{Fe}, \mathrm{Mn}$ and $\mathrm{Pb}$ concentrations in pore waters of Rosário salt marsh sediments vary seasonally. 
87 This paper reports the changes of $\mathrm{Fe}, \mathrm{Mn}, \mathrm{Zn}, \mathrm{Cu}, \mathrm{Pb}$ and $\mathrm{Cd}$ concentrations in pore water and flooding 88 water during the first 50 minutes of the tidal inundation over sediments of the Tagus salt marsh (Rosário) colonised by Spartina maritima and Sarcocornia fruticosa. On the basis of the registered concentrations it was estimated the diffusive fluxes between sediments and overlying water during submerged periods. In addition, it was calculated the amounts exported from the colonised sediments during the first 50 minutes of tidal inundation. The magnitude of the two contributions to the water column is discussed.

93

\section{Material and methods}

95

\subsection{Study area} The $340 \mathrm{~km}^{2}$ of the Tagus estuary represent one of the largest transitional systems in Europe. Almost $40 \%$ of the estuary is composed by inter-tidal mudflats and its southern and eastern shores contain extensive areas of salt marshes colonised by Sarcocornia fruticosa, Sarcocornia perennis, Halimione portulacoides and Spartina maritima. The marsh selected for this study (Rosário) is located in the southern shoreline of the estuary (Figure 1). It covers an area of 200 ha (Crespo, 1993), being characterized by homogeneous stands of S. maritima as a pioneer species in the lower part, pure stands of $H$. portulacoides across the 20-50 cm elevation transect, and $S$. fruticosa and $S$. perennis in the higher salt marsh. The marsh is fully inundated twice a day by tidal action (2-4m of tidal amplitude) through a highly branched system of channels that cross the elevation transect. The channels have 0.5 to $1.5 \mathrm{~m}$ depth promoting the inundation of the higher marsh even at low amplitude tides. The study area is located in the proximity of a heavy industrialised zone that includes several chemical plants. During the past four decades these industries discharged effluents enriched in various contaminants into the estuary that were transported towards the

110 Rosário marsh by the semi-diurnal tidal flooding.

112 Sediment cores of $30-\mathrm{cm}$ long were collected, as well as flooding water over the short period of tidal 113 inundation in the two sites of the Rosário salt marsh colonised by pure stands of $S$. fruticosa (high marsh) 114 and S. maritima (low marsh) and separated by less than 5 meters. Sampling took place in March 2008. At 115 low tide, four sediment cores were collected at each site, when sediment was exposed to the atmosphere, 116 and water retained in the main channel of the marsh was sampled by hand into acid pre-cleaned syringes. 117 One of the cores was sampled at each site to measure temperature, dissolved oxygen and salinity all 118 along its depth. When tidal water starts to flood each site, two additional sediment cores and flooding 119 water were collected at each time of inundation: 5, 10 and 50 minutes. Flooding water was sampled $1 \mathrm{~cm}$ 120 above the sediment surface directly into acid pre-cleaned syringes. All water samples were acidified with 121 suprapure $\mathrm{HCl}(\mathrm{pH}<2)$. The cores were sliced immediately after sampling in 5-cm layers, prepared 122 composite samples for each layer of the cores collected at each site, and material stored in acid 123 precleaned HDPE vials avoiding air presence inside. Sampling took place in less than three minutes. Core 124 material consisted of dense rooting sediments with no evidence of burrowing worms, crabs or bivalves. 125 The water and sediment samples were kept in refrigerated boxes and immediately transported to the

126 laboratory. A more detailed description of these sampling procedures can be found in previous works 127 (Caetano et al, 2007).

128

\section{2.3. Sample treatment}

130 Pore waters were separated from the sediment layers by centrifugation at 10160 rcf $x \mathrm{~g}$ for 30 minutes at $131+4^{\circ} \mathrm{C}$ and filtered through $0.45 \mu \mathrm{m}$ cellulose acetate membranes. Filtration and subsequent manipulation 
132 of the samples were carried out in a glove box under argon atmosphere in order to avoid alteration of the 133 initial conditions (Caetano et al., 2007; Santos-Echeandia et al., 2009). Pore-water samples were acidified 134 with suprapure $\mathrm{HCl}(\mathrm{pH}<2)$. The remaining solid material of each sediment layer was washed with Milli-Q 135 water $(18.2 \mathrm{M} \Omega . \mathrm{cm})$ smoothly using a teflon sieve of $212-\mu \mathrm{m}$ mesh size and tweezers to separate 136 belowground biomass from sediment particles. Sediment particles and belowground biomass of each layer 137 was oven dried at $40 \stackrel{\circ}{\circ} \mathrm{C}$ and homogenised with an agate mortar. Procedures were done in order to 138 subsequent determinations of total $\mathrm{Fe}, \mathrm{Mn}, \mathrm{Zn}, \mathrm{Cu}, \mathrm{Pb}$ and $\mathrm{Cd}$ concentrations in water, sediment and 139 biological samples.

140

\subsection{Methods}

142 Dissolved oxygen was measured in sediment layers using a Diamond Electro-Tech needle electrode 143 following the method described in Brotas et al. (1990). Temperature was measured with a Pt100 sensor. 144 The salinity of flooding and pore waters was measured using a conductivity electrode. Each composite 145 sample was divided in three subsamples and analyzed independently for trace metals. Total dissolved Mn 146 and $\mathrm{Fe}$ in overlying, flooding and pore waters were determined by graphite furnace atomic absorption 147 spectrometry (Varian SpectrAA Zeeman 220). Concentrations were determined using the interpolation 148 method in a previously designed calibration curve. Detection limits (defined as three times the standard 149 deviation) were $2.6 \mathrm{nM}$ for Fe and $1.9 \mathrm{nM}$ for Mn. The reproducibility, measured as the RSD was always 150 lower than $5 \%$. The rest of total dissolved metals $(\mathrm{Zn}, \mathrm{Cu}, \mathrm{Pb}$ and $\mathrm{Cd}$ ) were determined by means of 151 stripping voltammetry using a Metrohm VA-694 equipped with a hanging mercury drop electrode (HMDE) 152 as the working electrode, $\mathrm{Ag} / \mathrm{AgCl}$ as the reference electrode, and a Pt wire as the counter-electrode. Prior 153 to determination, samples were diluted (when necessary) and UV-digested for $1 \mathrm{~h}$ using UV-Digestor 154 equipped with a high-pressure mercury lamp of $200 \mathrm{~W}$ (Achterberg and Van Den Berg., 1994). The 155 simultaneous determination of $\mathrm{Zn}, \mathrm{Cu}, \mathrm{Pb}$ and $\mathrm{Cd}$ in the dissolved phase was carried out using the method 156 of standard additions by means of differential pulse anodic stripping voltammetry (DPASV). One blank was 157 run every five samples and results were blank-corrected. The accuracy of the analytical procedure was 158 assessed by the analysis of three different certified reference materials (CASS-4, SLEW-3 and SLRS-4), 159 obtaining good agreement with the certified concentrations (Table 1). The detection limits of the analytical 160 procedure, defined as three times the standard deviation of the blanks, were $0.5 \mathrm{nM}$ for $\mathrm{Zn}, 0.7 \mathrm{nM}$ for $\mathrm{Cu}$, $16122 \mathrm{pM}$ for $\mathrm{Pb}$ and $20 \mathrm{pM}$ for $\mathrm{Cd}$. The precision of the analysis measured as relative standard deviation 162 was: $5-10 \%$ for $\mathrm{Zn}$ (at $20 \mathrm{nM}$ ), $5-10 \%$ for $\mathrm{Cu}$ (at $10 \mathrm{nM}$ ), $5-10 \%$ for $\mathrm{Pb}$ (at $300 \mathrm{pM}$ ) and $25-40 \%$ for $\mathrm{Cd}$ (at $16360 \mathrm{pM})$.

164 Approximately $100 \mathrm{mg}$ of sediment was mineralized completely with $6 \mathrm{~cm}^{3}$ of $\mathrm{HF}(40 \%)$ and $1 \mathrm{~cm}^{3}$ of 165 Aqua-Regia ( $\mathrm{HCl}-36 \%: \mathrm{HNO}_{3}-60 \%$; 3:1) in closed Teflon bombs at $100^{\circ} \mathrm{C}$ during 1 hour. The bomb 166 contents were evaporated to near dryness in Teflon vials, redissolved with $\mathrm{HNO}_{3}$, heated for 20 min at 75 $167 \stackrel{\circ}{\mathrm{C}}$ and diluted to $50 \mathrm{~cm}^{3}$ with Milli-Q water (Caetano et al., 2008). Plant material ( $\approx 200 \mathrm{mg}$ ) was digested 168 with a mixture of $\mathrm{HNO}_{3}(60 \%)$ and $\mathrm{H}_{2} \mathrm{O}_{2}(30 \%)$ in Teflon bombs at $60 \stackrel{\circ}{\circ} \mathrm{C}$ for 12 hours and at $100 \stackrel{\circ}{\circ} \mathrm{C}$ for 1 169 hour. Two procedural blanks were prepared using the same analytical procedure and reagents, and 170 included within each batch of 20 samples. Iron, $\mathrm{Mn}$ and $\mathrm{Zn}$ were analysed by flame atomic absorption 171 spectrometry (Perkin Elmer AA100) with an air-acetylene flame. Metal concentrations were determined 172 with the standard additions method. Concentrations of $\mathrm{Cu}, \mathrm{Pb}$ and $\mathrm{Cd}$ were determined using a 173 quadrupole ICP-MS (Thermo Elemental, X-Series) equipped with a Peltier Impact bead spray chamber 174 and a concentric Meinhard nebulizer. Coefficients of variation for metal counts $(n=5)$ varied between 0.5 175 and $2 \%$. The precision and accuracy of each metal concentration measurements, determined through 176 repeated analysis of certified references materials (MESS2, PACS2 and MAG1 for sediment and BCR60 
177 and BCR61 for plant material) (Table 1), using In as internal standard, were 1-4\% and 2-5\%, respectively

178 (data not shown). Procedural blanks always accounted for less than $1 \%$ of the total metal concentrations in

179 samples.

180

181

182 2.5. Estimation of sediment-water exchange

183 Different levels of trace metals between pore waters of upper sediment layers and overlying water imply 184 their export/import to/from the water column. Since inter-tidal sediments are alternatively covered with 185 water and exposed to the atmosphere, two types of fluxes should be considered: diffusive fluxes during the 186 submerged period and advective transport associated with the tidal flooding.

187 Diffusive flux. On the basis of the measured concentration profiles, the benthic fluxes of trace metals are 188 predicted by Fick's first law of diffusion (Berner, 1980):

$189 \quad F_{\text {dif }}=\phi D_{\mathrm{s}}\left(\mathrm{C}_{0}-\mathrm{C}_{\mathrm{p}}\right) / \Delta x$

190 where $\phi$ is the porosity, $D_{s}$ is the diffusion coefficient, $C_{0}=[\mathrm{Me}]$ in pore water of the topmost sediment 191 layer, $C_{p}=[\mathrm{Me}]$ in overlying water and $x$ is the space co-ordinate, negative into sediment and origin at sediment-water interface. Sediment porosity $(\phi)$ was calculated from the following equation:

$$
\phi=m_{P W} /\left(m_{P W}+m_{S} / 2.65+m_{R} / 1.2\right)
$$

194 where $m_{P W}$ represents the pore water mass, $m_{S}$ the sediment solids mass and $m_{R}$ the roots mass. The 1952.65 value is the density of the sediment considering to be formed by pure mud (Berner, 1980) and the 1.2 is the density of the roots. The diffusion coefficient $\left(D_{s}\right)$ was calculated from the following equation:

$$
D_{S}=\phi^{2} D_{0}
$$

198 where $D_{0}$ represents the diffusion coefficient of a metal at a given temperature (calculated from $\mathrm{Li}$ and 199 Gregory, 1974).

200 Advective flux. As tidal water floods over inter-tidal sediments the pore water solutes tends to be exported. 201 The associated pressure difference and tidal water movement are the driven mechanism for this export. By 202 using the temporal variation of trace metals concentrations in the flooding water the advective transport ( $T$ ) 203 to the water column are calculated using the following expression (Caetano et al., 2007):

$$
T=\Sigma\left[\left(\mathrm{C}_{\mathrm{t}+1}-\mathrm{C}_{\mathrm{t}}\right) / 2-\mathrm{C}_{\mathrm{i}}\right]\left(\mathrm{h}_{\mathrm{t}+1}-\mathrm{h}_{\mathrm{t}}\right)
$$

205 where $\mathrm{C}_{\mathrm{t}+1}$ and $\mathrm{C}_{\mathrm{t}}$ are [Me] in the flooding water at times $t+1$ and $t$ and $\mathrm{h}_{\mathrm{t}+1}, \mathrm{C}_{\mathrm{i}}$ is the residual concentration 206 (lowest value obtained for the flooding water) and $h_{t}$ are the water depth at the same times. It was observed that water depth during the field measurements increased on the average 0.5 and $1 \mathrm{~cm}$ each minute of inundation in $S$. fruticosa and $S$. maritima areas, respectively. The transport of trace metals is calculated for the first 50 minutes of inundation. Since inter-tidal sediments are inundated twice a day, the advective daily flux ( $T$ ) was multiplied by a factor of two.

\subsection{Statistics}

213 Statistical software (Statistica 7.0) was used for statistical analyses. Considering the number of samples, 214 analysis was performed by the non-parametric Kruskal-Wallis test in order to detect metal concentrations 215 differences in sediment solids, belowground biomass and pore water. Correlations between parameters 216 were searched by Spearman rank correlations $(p<0.05)$.

\section{Results}

220 


\subsection{Metal concentrations in rooting sediments}

222 The rooting sediments from the two sampling sites contained between 10.2 and $12.3 \%$ of $\mathrm{Al}$, a proxy for

223 the preponderance fine grain particles (Windom et al, 1989). The sediments colonised by $S$. fruticosa

224 presented significantly higher levels of $\mathrm{Pb}(\mathrm{p}<0.05), \mathrm{Zn}, \mathrm{Cu}$ and $\mathrm{Cd}(\mathrm{p}<0.1)$ than by $\mathrm{S}$. maritima (table 2).

225 Maximum concentrations reached 290, 2408, 83 and $4.1 \mu \mathrm{g} \mathrm{g}^{-1}$, respectively. The depth variation of the

226 metal concentration differed in the two sampling sites. Whereas the first $15-\mathrm{cm}$ depth of sediments

227 colonised by S. maritima exhibited elevated concentrations of $\mathrm{Cu}$ and $\mathrm{Pb}$, the $15-25 \mathrm{~cm}$ layers of

228 sediments colonised by S. fruticosa showed enhanced levels of $\mathrm{Cd}$ and $\mathrm{Zn}$.

\section{$230 \quad$ 3.2. Plant belowground biomass}

231 Belowground biomass of the two plants was concentrated in the upper 15-cm depth, decreasing uniformly

232 with the depth (table 3). The belowground biomass of $S$. fruticosa $3873 \mathrm{~g} \mathrm{~m}^{-2}$, calculated as the amount 233 present the upper $25-\mathrm{cm}$, exceeded $1292 \mathrm{~g} \mathrm{~m}^{-2}$ found for $S$. maritima. The roots of $S$. maritima were 234 thicker (maximum diameter of $3 \mathrm{~mm}$ ) than the roots of $S$. fruticosa that were usually $<1 \mathrm{~mm}$. These 235 observations combined with biomass point to a higher specific surface area of the belowground biomass of 236 S. fruticosa.

\subsection{Metal concentrations in belowground biomass}

239 The concentrations of $\mathrm{Cu}, \mathrm{Cd}$ and $\mathrm{Pb}$ differed significantly $(\mathrm{p}<0.05$ and $\mathrm{p}<0.1)$ in the belowground biomass

240 of the two plants (Table 3). The metal concentration varied with the depth, although levels were not 241 correlated to the quantity of roots presented at each layer. In fact, roots in the first 5-cm sediment layer 242 contained generally lower metal concentrations than in deeper layers with elevated biomass. The most 243 noticeable aspect is the accumulated levels of metals $(\mathrm{Cu}, \mathrm{Pb}$ and $\mathrm{Cd}$ ) in roots being one order of 244 magnitude above the concentrations found in the corresponding rooting sediments (tables 2 and 3). The 245 maximum concentrations $\left(\mu \mathrm{g} \mathrm{g}^{-1}\right)$ in belowground biomass of $S$. maritima and $S$. fruticosa were:3571 and $24611017(\mathrm{Zn}), 212$ and $334(\mathrm{Cu}), 1528$ and $2739(\mathrm{~Pb})$ and 19 and $30(\mathrm{Cd})$, ) respectively.

\subsection{Pore water characteristics of sediments under air-exposed conditions}

249 Temperature of air-exposed sediments in the sampling period (early morning) ranged within a narrow 250 interval $\left(14-15^{\circ} \mathrm{C}\right)$ and showed no substantial differences between higher and lower marsh, and with the 251 depth. Table 4 presents the maximum and minimum values of parameters in pore waters of sediments 252 colonised by the two plants under air-exposed conditions. Salinity varied from lower (32.4-33.6\%) to higher marsh (28.5-31.8\%o), reflecting freshwater drainage to the upper area colonised by $S$. fruticosa. In both cores dissolved oxygen remained $<2 \mu \mathrm{M}$ at all depths. Maximum values of dissolved $\mathrm{Fe}$ and $\mathrm{Mn}$ in sediments colonised by $S$. maritima and $S$. fruticosa were in the same order of magnitude (12.7 and 65.3 $\mu \mathrm{M}$ of $\mathrm{Fe}$ and 34.4 and $14.5 \mu \mathrm{M}$ of $\mathrm{Mn}$, respectively). On the contrary, dissolved levels of the analysed trace elements were one order of magnitude higher in the area colonised by $S$. fruticosa. The differences had higher significance for $\mathrm{Zn}, \mathrm{Cu}$ and $\mathrm{Pb}(\mathrm{p}<0.001)$ than for $\mathrm{Cd}(\mathrm{p}<0.05)$. Concentrations in pore waters of S. maritima and S. fruticosa reached: 1.2 and $20.6 \mu \mathrm{M}(\mathrm{Zn}), 28$ and $201 \mathrm{nM}(\mathrm{Cu}), 15$ and $268 \mathrm{nM}(\mathrm{Pb}), 1.4$ and $75 \mathrm{nM}(\mathrm{Cd})$, respectively.

\subsection{Time variation of metal concentrations in pore waters}

263 Figures 2 and 3 compare the depth metal concentrations in pore waters of sediments at air-exposed 264 conditions $(t=0), 5,10$ and 50 minutes after the tidal flooding of the marsh. Vertical concentrations at these 
periods of time varied with the analysed elements at the two surveyed sites. It is remarkable that pore waters at $\mathrm{t}=5 \mathrm{~min}$. of the surface sediment layers in the marsh colonised by $S$. maritima exhibited lower metal concentrations than at $\mathrm{t}=0$ (Figure 2). The differences were less clear for the higher marsh covered with S. Fruticosa (Figure 3), meaning that tidal inundation had a lower effect on the modification of pore water chemistry. The profiles at 10 and 50 minutes inundation pointed to establishing conditions towards those registered at air-exposed period. This tendency was better observed in the lower marsh. The shape of profiles differs in the two sites. Whereas pore waters from the upper layers of the lower mash showed higher metal concentrations, sub-surface maxima were found the pore waters of sediments covered by $S$. fruticosa.

\subsection{Metal concentrations in flooding water}

276 The levels of $\mathrm{Fe}, \mathrm{Mn}, \mathrm{Zn}, \mathrm{Cu}, \mathrm{Pb}$ and $\mathrm{Cd}$ in the dissolved fraction of flooding water over the two sites of the marsh increased abruptly in the first 2 to 5 minutes of inundation (figure 4). The sharp concentration peaks $(\mathrm{Fe}=60 \mu \mathrm{M}, \mathrm{Mn}=7.5 \mu \mathrm{M}, \mathrm{Zn}=2.5 \mathrm{nM}, \mathrm{Cu}=550 \mathrm{nM}, \mathrm{Pb}=100 \mathrm{nM}, \mathrm{Cd}=1.7 \mathrm{nM}$ ) reached one to two orders of magnitude above the values found in subsequent periods of inundation. Furthermore, these maximum values are within the range of levels registered in pore waters (table 4). The maximum of $\mathrm{Fe}, \mathrm{Mn}, \mathrm{Cu}$ and $\mathrm{Cd}$ concentrations in the area colonised by $S$. fruticosa exceeded the values observed in lower marsh ( $S$. maritima).

283

\section{Discussion}

A noticeable remark of the present work is the consistent differences on of belowground biomass and $\mathrm{Zn}$, $\mathrm{Cu}, \mathrm{Pb}$ and $\mathrm{Cd}$ concentrations in solid fine sediments, roots and pore waters between sites colonised by $\mathrm{S}$. maritima and S. fruticosa. Higher values were registered in the sediment column of the upper marsh covered by $S$. fruticosa. Despite the daily flooding of the full marsh by the tide, differences of metal concentrations in pore waters stand.

\subsection{The influence of belowground biomass on metal retention}

293 The sediments of the Rosário marsh and adjacent inter-tidal flats consist of fine particles contaminated by discharges of the industrial complex localised in the southern part of the Tagus estuary. Various works have pointed to the retention of these contaminants in inter-tidal flats (Vale, 1990) and in the adjoining salt marshes (Caçador and Vale, 2001; Caetano et al., 2007). However, the levels of anthropogenic metals in marsh sediments exceed largely the values found in the non-vegetated sediments (Caçador et al., 1993, 1996a,b, 2000). The enrichment is confined to the rooting sediments and varies with the plant species that cover the marsh sediment. The differences found on metal concentrations between sediments colonised by $S$. maritima and $S$. fruticosa corroborate the previous findings.

301 The iron-oxides plaque found on roots of plants in northern European and US marshes (Otte et al., 1989;

302 Mendelssohn et al., 1995; St-Cyr and Campbell, 1996; Cambrolle et al., 2008) increases the thickness in 303 Tagus marshes to form hollow cylinders around the roots (Vale et al., 1990). The growth of these 304 structures results from the reaction between $\mathrm{O}_{2}$, which is delivered by roots during most time of the year, and Fe (II) in pore waters that diffuses towards the roots (Sundby et al., 1998)). As observed in other marshes (St-Cyr and Crowder 1990, Otte 1991, St-Cyr and Campbell 1996), trace elements are incorporated in the iron-oxides (Vale et al., 1990; Caetano and Vale, 2002; Vale et al., 2003). However, significant relationships between trace elements and Fe concentration in the bulk rooting sediments of the two sites were not found $(p \square 0,05)$, suggesting that Fe precipitates are not the major driver to retain trace 
310 elements in sediments colonised by $S$. fruticosa and $S$. maritima. Enhanced levels of total Fe and $\mathrm{Mn}$ in

311 the $0-5 \mathrm{~cm}$ layer may indicate the precipitation of oxides by the $\mathrm{O}_{2}$ diffused from the surface rather than

312 delivered by roots. Since these plants have a short or absence of dormancy in winter (Catarino and

313 Caçador, 1981) it is unlike a stop on the $\mathrm{O}_{2}$ deliver. Therefore the lack of oxygen observed in the sediment 314 column may indicate that compounds, like ammonium and sulphide, have consumed the supplied $\mathrm{O}_{2}$.

315 Reduced species of $\mathrm{Fe}$ and $\mathrm{Mn}$ are also oxidised by root-derived oxygen, although the higher background

316 concentration do not allow differentiating until oxygen is in excess. Nevertheless, it appears that oxygen

317 delivered by the roots was not used to oxidise substantial amounts of $\mathrm{Fe}$ (II) in $\mathrm{Fe}$ (III) and of $\mathrm{Mn}$ (II) in

$318 \mathrm{Mn}(\mathrm{IV})$ and enhance the $\mathrm{Fe}$ and $\mathrm{Mn}$ in solid sediments, since sediment layers of higher belowground

319 biomass did not present increases of these elements.

320 Previous works on the Tagus marshes indicated a correlation between metal concentration in rooting 321 sediments and loss on ignition (Caçador et al., 1999). These relationships pointed to the importance of 322 organic matter, which at these layers derives mainly from the decomposing roots, on retention of trace 323 elements (Jones, 1998; Weis and Weis, 2004). This effect may be emphasised in marshes with abundant 324 belowground biomass, like the Rosário site colonised by $S$. fruticosa. Because belowground biomass of 325 this plant was found to have an elevated specific area (Sundby et al., 2005), sediment-pore water 326 interaction is expected to be higher than in the sediments covered with S. maritima. The enhancement of 327 this interaction, among others related to the different strategies of the two studied plants (Groenendijk and 328 Vink-Lieavaart, 1987; Caetano et al., 2008), may induce higher levels of trace elements found in the roots 329 of $S$. fruticosa in comparison to the $S$. maritima. A study of metal release from decomposing root litter in 330 Tagus marshes over a 7-month period pointed to complex behaviour of the surveyed metals. Litter in 331 spring may act as a cation exchanger adsorbing $\mathrm{Cu}$ and $\mathrm{Pb}$ from sediments, while $\mathrm{Zn}$ and $\mathrm{Cd}$ stocks 332 decreased progressively in plants (Pereira et al, 2007; Caçador et al., 2009). As metals exchange with the 333 decomposing litter the metal concentrations in pore waters may enhance. The litter decomposition and the 334 release of exudates from live roots are a continuous source of organic matter that has direct impact on 335 metals availability (Sundby et al., 2005; Pereira et al, 2007). In a previous study over the annual growth 336 cycle dissolved sulphide was absent in rooting sediments, even in periods of lack of oxygen (Sundby et al., 337 2003). Assuming similar conditions in the sediment, no substantial amounts of metals in pore waters are 338 expected to precipitate as metal sulphides. In the absence of this effective removal, the peak 339 concentrations of dissolved $\mathrm{Cu}, \mathrm{Cd}, \mathrm{Pb}$ and $\mathrm{Zn}$ in pore waters are presumably linked to organic complexes 340 stabilized in solution.

\subsection{Metal exchange between sediment and overlying water at submerged period}

343 Vertical pore water profiles differed in the two studied sites. At 50-min after inundation of the marsh and at 344 air-exposed conditions, S. maritima sediments exhibited in general higher levels of $\mathrm{Fe}, \mathrm{Mn}, \mathrm{Zn}, \mathrm{Cu}, \mathrm{Pb}$ and $345 \mathrm{Cd}$ in pore waters of the upper layers. Pore waters of $S$. fruticosa sediments showed a sub-surface 346 maximum of $\mathrm{Zn}, \mathrm{Pb}$ and $\mathrm{Cd}$ concentrations below the layers of higher root biomass (table 3) and of $\mathrm{Cu}$ 347 levels at layers of higher root density. The different metal concentration between pore water of $0-5 \mathrm{~cm}$ 348 layer and overlying water induce a diffusive flux estimated by the Fick's $1^{\text {st }}$ law (equation 1 ). The similarity 349 of concentrations at $\mathrm{t}=50 \mathrm{~min}$. of inundation and at air-exposed conditions ( $\mathrm{t}=0)$ suggests that no 350 exchanges are foreseen by molecular diffusion after that period of inundation. The best estimation for pore 351 water concentrations under submerged period is, thus, the average between concentration at $t=50$ min and

$352 \mathrm{t}=0$ (assumed as representative of the final submerged period). It was considered that sediments covered 353 by $S$. maritima and $S$. fruticosa are submerged 6 and 4 hours per tide, respectively. Table 5 shows the 354 predicted amounts ( $\mathrm{nmol} \mathrm{m} \mathrm{d}^{-2} \mathrm{~d}^{-1}$ ) of metals exchanged daily with the overlying water. Sediments covered 
355 by S. maritima imported $\mathrm{Cu}$ and $\mathrm{Zn}\left(-16\right.$ and $\left.-137 \mathrm{nmol} \mathrm{m}^{-2} \mathrm{~d}^{-1}\right)$ and exported $\mathrm{Fe}, \mathrm{Mn}, \mathrm{Pb}$ and $\mathrm{Cd}(105$, $3564800,0.4$ and $0.04 \mathrm{nmol} \mathrm{m}^{-2} \mathrm{~d}^{-1}$, respectively). The sediments colonised by $S$. fruticosa exported larger 357 amounts of $\mathrm{Zn}, \mathrm{Mn}, \mathrm{Cu}$ and $\mathrm{Cd}(570,290,80$ and 8, respectively) and imported $\mathrm{Fe}$ and $\mathrm{Pb}(-510$ and -4 ,

358 respectively). In these calculations it was considered the value of porosity $(\phi)$ in equation (2) commonly 359 used for fine sediments. However, the presence of micro-channels around the belowground plant parts

360 near the sediment-water interface may facilitate the exchange of solutes by molecular diffusion. Therefore 361 exchanges of metals between sediment-water interfaces driven by diffusive gradients are underestimated.

362

\section{4.3. Effect of tidal flooding on metal concentration in pore waters and overlying water}

364 The decrease of metal concentrations in pore water during the first 5 and 10 minutes of inundation (figures

3652 and 3) clearly indicates that tidal flooding modifies the chemical equilibrium in pore water of the upper

366 sediment layers. These results are in line with studies performed in Ria Formosa (SW Europe) showing the 367 modification of nutrients, $\mathrm{Cu}$ and $\mathrm{Cd}$ profiles in pore water as permeable inter-tidal sediments are flooded 368 (Falcão and Vale, 1990; Caetano et al, 2007). During inundation overlying water containing lower metal 369 concentrations mixes with pore waters of the upper sediment layers. Alterations associated with 370 precipitation/dissolution and sorption/desorption during this period should not also be excluded (Caetano 371 et al., 1997; Heuttel et al., 1998). In general, profiles registered 50 minutes after the inundation were closer 372 to the initial conditions suggesting that equilibrium have been nearly achieved. In the first minutes of tidal 373 flooding all determined elements increased considerably their concentrations in water that inundates the 374 sediments from both sites. The abrupt increases are in line with the decreases of metal concentrations in 375 pore water pointing to a substantial pulse of solutes exported to the water column. Although different 376 trends on pore water concentration were found between both plants during the inundation the overall 377 process induced by tide was similar in S.maritima and S. Fruticosa.

\subsection{Advective transport of metal associated to tidal flooding}

380 The increase of metal concentrations in overlying waters during the first minutes of tidal flooding is 381 coherent with the decrease on the pore waters and points to the escape of metals from pore water of salt 382 marsh sediments (figure 3). On the basis of these measurements one may calculate the advective 383 transport to the water column using the equation (4). Table 4 presents the amounts of $\mathrm{Fe}, \mathrm{Mn}, \mathrm{Zn}, \mathrm{Cu}, \mathrm{Pb}$ 384 and $\mathrm{Cd}$ on a daily basis, which correspond to the sum of two pulses associated with the two tidal flooding periods. The most remarkable aspect is that quantities are three to four orders of magnitude above those predicted by Fick's $1^{\text {st }}$ law. For example, the diffusive flux of $\mathrm{Pb}$ was between -4 and $0.4 \mathrm{nmol} \mathrm{m} \mathrm{m}^{2}$ while advective transport reached $13-15 \times 10^{3} \mathrm{nmol} \mathrm{m}^{2} \mathrm{~d}^{-1}$. Previous works on permeable inter-tidal sediments have shown the importance of pulse mechanisms associated with the tidal flushing on sediment-water exchanges (Falcão and Vale, 1990; Caetano et al, 2007). The current work permits to extend the relevance of this mechanism to salt marsh sediments coved with $S$. maritima and $S$. fruticosa, two plants commonly found in south European salt marshes.

392 Although sediments of Rosário marsh consist of fine-grained sediments, the micro-channels formed by the 393 root mosaic have probably a major role on water and solutes circulation driven by the increase of pressure 394 on sediments as tide inundates the area. The amounts exported by this mechanism were higher in $S$. 395 maritima than in S.fruticosa area, although the metal concentration in pore waters of sediments covered by 396 this plant exceeded largely that found in S. maritima. The most plausible explanation for this apparent 397 discrepancy is the smaller size of the $S$. fruticosa roots and their random and intricate distribution which 398 create more obstacles to pore water flushing during the first moments of tidal flooding. Otherwise, $S$. 399 maritima has thicker tillers and roots promoting increased exchanges between pore water and flooding 
waters. These results are important from an ecological point-of-view since marshes subjected to tidal inundations also act as a source of dissolved metals from sediment to the water column being available for macrobenthic organisms and small fishes. These findings also support a previous works that showed the transfer of trace metals to marine environment across the detritus generated by salt marsh plants (Pereira et al, 2007; Caçador et al., 2009). Considering the magnitude and the periodicity of advective export, successive tidal inundation would deplete the poll of metals in the salt marsh sediment if not balanced by equivalent inputs. Conservation of mass requires an import during the submerged period by settling of suspended particles, advection of water, deposition of particles during ebb tide and exchanges of metals with belowground biomass.

409

\section{Conclusions}

411 This work emphasizes the importance of tidal flooding over salt marsh sediments to the metal exportation 412 to the water column. The accumulation of metals in the sediments close to the plant roots, together with 413 the arriving of the tide results in an important exportation of metals from the pore water of salt marsh areas 414 to the overlying waters. More than the diffusive flux, the advective transport has been demonstrated to be 415 an important contribution to the overall flux. This type of fluxes should be taken into account when 416 assessing trace metal contamination problems and remediation in salt marsh areas. Furthermore, one may 417 speculate that inundation of coastal areas associated with the climatic changes, either to increase of water 418 levels or floods will result in additional fluxes of trace elements from intertidal areas to the water column.

\section{Acknowledgments}

The authors wish to thank the colleagues Rute Cesário (IPIMAR) and Ana García-Blanco (IIM-CSIC) for the field work and technical assistance. This article is a contribution to the Spanish-Portuguese Actions of references 2007PT0021 and FCT/CSIC9/CSIC/08. Dr. Santos-Echeandía would like to thank the Basque Government for the financial support (post-doctoral contract).

426

427

428

\section{References}

Achterberg, E. P., Van Den Berg C., 1994. In-line ultraviolet-digestion of natural water samples for trace metal determination using an automated voltammetric system. Analytica Chimica Acta 291, 213232.

Aller, R., 1977. The influence of macrobenthos on chemical diagenesis of marine sediments. PhD Thesis, Yale University, USA.

436 Brotas, V., Ferreira, A., Vale, C., Catarino, F., 1990. Oxygen profiles in intertidal sediments of Ria Formosa (S. Portugal). Hydrobiologia 207, 123-129.

438 Brune, A., Frenzel, P., Cypionka, H., 2000. Life at the oxic-anoxic interface: microbial activities and 439 adaptations. FEMS Microbiology Reviews 24, 691-710.

440 Burdige, D., 1993. The biogeochemistry of manganese and iron reduction in marine sediments. Earth Science Reviews 35, 249-284.

442 Caçador, I., Vale C., 2001. Salt marshes, in: Prasad, M., editor. Metals in the Environment. Hyderabad: Marcel Dekker Inc. p. 95-115. 
444

445

446

447

448

449

450

451

452

453

454

455

456

457

458

459

460

461

462

463

464

465

466

467

468

469

470

471

472

473

474

475

476

477

478

479

480

481

482

483

484

485

486

487

488

Caçador, I., Vale, C., Catarino, F., 1993. Effects of plants on the accumulation of $\mathrm{Zn}, \mathrm{Pb}, \mathrm{Cu}$ and $\mathrm{Cd}$ in sediments of the Tagus estuary salt marshes, Portugal. J-P. (Vernet ed.). Environmental Contamination. Elsevier. Amsterdam Studies in Environmental Science 55, 355-365.

Caçador, I., Vale, C., Catarino, F., 1996a. Accumulation of Zn, Pb, Cu and Ni in sediments between roots of the Tagus estuary salt marshes, Portugal. Estuarine Coastal and Shelf Sciences 42, 393-403.

Caçador, I., Vale, C., Catarino, F., 1996b. The influence of plants on concentration and fractionation of Zn, $\mathrm{Pb}$, and $\mathrm{Cu}$ in salt marsh sediments (Tagus Estuary, Portugal). Journal of Aquatic Ecosystems Health 5, 193-198.

Caçador, I., Vale, C., Catarino, F., 1999. Relationship between metal concentrations and organic matter content in the Tagus estuary salt marsh sediments, in: Halophyte use in different climates Backhuys Publishers, Leiden, The Nertherlands.

Caçador, I., Vale, C., Catarino, F., 2000. Seasonal variation of Zn, Pb, Cu and Cd concentrations in the root-sediment system of Spartina maritima and Halimione portulacoides from Tagus estuary salt marshes. Marine Environmental Research 49, 279-290.

Caçador, I., Costa, A., Vale, C., 2004. Carbon storage in Tagus salt marsh sediments. Water Air Soil Pollution: Focus 4, 701-714.

Caçador, I., Caetano, M., Duarte, B., Vale, C., 2009. Stock and losses of trace metals from salt marsh plants. Marine Environmental Research 67, 75-82.

Caetano, M., Vale, C., 2002. Retention of arsenic phosphorus in iron-rich concretions of Tagus salt marshes. Marine Chemistry 79, 261-271

Caetano, M., Fonseca, N., Cesário, R., Vale, C., 2007. Mobility of Pb in salt marshes recorded by total content and stable isotopic signature. Science Total Environment 380, 84-92.

Caetano, M., Falcão, M., Vale, C., Bebianno, M., 1997. Tidal flushing of ammonium, iron and manganese from inter-tidal sediment pore waters. Marine Chemistry 58, 203-211.

Caetano, M., C. Vale, R. Cesário e N. Fonseca, 2008. Evidence for preferential depths of metal retention in roots of salt marsh plants. Science of the Total Environment 390, 466-474.

Cambrollé, J., Redondo-Gómez, S., Mateos-Naranjo, E., Figueroa, M.E., 2008. Comparison of the role of two Spartina species in terms of phytostabilization and bioaccumulation of metals in the estuarine sediment. Marine Pollution Bulletin 56, 2037-2042.

Catarino, F., Caçador, I., 1981. Produção de biomassa estratégia de desenvolvimento em Spartina maritima e outros elementos da vegetação dos sapais do estuário do Tejo. Boletim Sociedade Broteriana 2, 384-403.

Clothier, B., Green, S., 1997, Roots: the big movers of water and chemicals in soil. Soil Science 162, 534543.

Crespo, R., 1993. Cartografia do habitat potencial de Passeriformes no Estuário do Tejo por processamento digital de imagem. Degree Thesis FC - University of Lisbon, Lisbon.

Froelich, P., G. Klinkhammer, M. Bender, N. Luedtke, G. Heath, D. Cullen, P. Dauphin, D. Hammond, B. Hartman and V. Maynard, 1979. Early oxidation of organic matter in pelagic sediments of the eastern equatorial Atlantic: suboxic diagenesis. Geochimica et Cosmochimica Acta 43, 1075-1091.

Falcão, M., Vale, C. 1990. Study of the Ria Formosa ecosystem: benthic nutrient remineralization and tidal variability of nutrients in the water. Hydrobiologia 207, 137-146.

Groenendijk, A., Vink-Lieavaart, M., 1987. Primary production and biomass on a Dutch salt marsh: Emphasis on the belowground component. Vegetatio 70, 21-27.

Haines, B., Dunn, E., 1985. Coastal marshes, in: Chabot B, Mooney H, editors. Physiological Ecology of North American Plant Communities. London: Chapman and Hall. p. 323-47. 
489

490

491

492

493

494

495

496

497

498

499

500

501

502

503

504

505

506

507

508

509

510

511

512

513

514

515

516

517

518

519

520

521

522

523

524

525

526

527

528

529

530

531

Heuttel, M., Ziebis, W., Forster, S., Luther, G., 1998. Advective transport affecting metal and nutrient distributions and interfacial fluxes in permeable sediments. Geochimica et Cosmochimica Acta 62, 613-631.

Li, Y., Gregory, S., 1974. Diffusion of ions in sea water and in deep-sea sediments. Geochimica et Cosmochimica Acta 38, 703-714.

Jacob, D., Otte, M., 2003. Conflicting processes in the wetland plant rhizosphere: metal retention or mobilization? Water Air Soil Pollution 3, 91-104.

Jones, D., 1998. Organic acids in the rhizosphere-a critical review. Plant and Soil 205, 24-44.

Koretsky, C., Cuellar, A., Haveman, M., Beuving, L., Shattuck, T., Wagner, M., 2008a. Influence of Spartina and Juncus on saltmarsh sediments. II. Trace element geochemistry. Chemical Geology 255, 100-113.

Koretsky, C., Haveman, M., Cuellar, A., Beuving, L., Shattuck, T., Wagner, M., 2008b. Influence of Spartina and Juncus on saltmarsh sediments. I. PoreWater Geochemistry. Chemical Geology 255, 87-99.

Mendelssohn, I., Kleiss, B., Wakeley, J., 1995. Factors controlling the formation of oxidising root channels: a review. Wetlands 15, 37-46.

Otte, M.L., Rozema, J., Koster, L., Haarsma, M.S., Broekman, R.A., 1989. Iron plaque on roots of Aster tripolium L.: interaction with zinc uptake. New Phytologist 111, 309-317.

Otte, R., 1991. Heavy metals and arsenic in vegetation of salt marshes and floodplains. PhD Thesis, Vrije Universiteit, Amsterdam.

Pereira, P., Caçador, I., Vale, C., Caetano, M., Costa, A., 2007. Decomposition of belowground biomass litter and metal dynamics in salt marshes (Tagus Portugal). Science Total Environment 380, 93101.

Reboreda, R., Caçador, I., 2007. Copper, zinc and lead speciation in salt marsh sediments colonised by Halimione portulacoides and Spartina maritima. Chemosphere 69, 1655-1661.

Santos-Echeandia, J., Prego, R., Cobelo-García, A., Millward, G.E., 2009. Porewater geochemistry in a Galician Ria (NW Iberian Peninsula): Implications for benthic fluxes of disolved trace elements (Co, Cu, Ni, Pb, V, Zn). Marine Chemistry 117, 77-87.

St-Cyr, L., Campbell, P., 1996. Metals (Fe, Mn, $\mathrm{Zn}$ ) in root plaque of submerged aquatic plant collected in situ: Relations with metal concentrations in adjacent sediments and in the root tissue. Biogeochemistry 33, 45-76.

St-Cyr, L., Crowder, A., 1990. Manganese and copper in the root plaque of Phragmites autralis. Soil Science 149, 191-198.

Sundby, B., Vale, C., Caçador, I., Catarino, F., Madureira, M., Caetano, M., 1998. Metal-rich concretions on the roots of the salt marsh plants: mechanism and rate of formation. Limnology and Oceanography 43, 245-252.

Sundby, B., Vale, C., Caetano, M., Luther, G., 2003. Redox chemistry in the root zone of a salt marsh sediment in the Tagus estuary, Portugal. Aquatic Geochemistry 9, 257-271.

Sundby, B., Caetano, M., Vale, C., Gobeil, C., Luther, G., Nuzzio, D., 2005. Root-induced cycling of lead in salt marsh sediments. Environmental Science and Technology 39, 2080-2086.

Sundby, B., 2006. Transient state diagenesis in continental margin muds. Marine Chemistry 102, 2-12.

Taillefert, M., Neuhuber, S., Bristow, G.W., 2007. The effect of tidal forcing on biogeochemical processes in intertidalsalt marsh sediments. Geochemical Transactions 8,6. 
532 Vale, C., Catarino, F., Cortesão, C., Caçador, I., 1990. Presence of metal-rich rhizoconcretions on the 533 roots of Spartina maritima from the salt marshes of the Tagus Estuary, Portugal. Science of the Total Environment 97/98, 617-626.

535 Vale, C., Caetano, M., Raimundo, J., 2003. Incorporation of trace elements in iron-rich concretions around 536 plant roots of Tagus estuary salt marshes (Portugal). Journal of Soils and Sediments 3, $208-212$.

537 Vale, C., 1990. Temporal variations of particulate metals in the Tagus river estuary. Science of the Total 538 Environment 97, 137-154.

539 Van Cappellen, P., Y. Wang, 1996. Cycling of iron and manganese in surface sediments: a general theory 540 for the coupled transport and reaction of carbon, oxygen, nitrogen, sulphur, iron and manganese. $541 \quad$ American Journal Science 296, 197-243.

542 Weis, J., Weis, P., 2004. Metal uptake, transport and release by wetland plants: implications for 543 phytoremediation and restoration. Environmental International 30, 685-700.

544 Windham, L., Weis, J., Weis, P., 2001. Lead uptake, distribution, and effects in two dominant salt marsh 545 macrophytes, Spartina alterniflora (Cordgrass) and Phragmites australis (Common reed). Marine Pollution Bulletin 42, 811-816.

Windom, H., Schropp, S., Calder, F., Ryan, J., Smith, R., Burney, L., Lewis, F.G., Rawlison, C.H., 1989. Natural trace metal concentrations in estuarine and coastal marine sediments of the southeastern United States. Environmental Science and Technology 23, 314-320. 


\section{ACCEPTED MANUSCRIPT}

Table 1. Certified values and measured average concentrations of $\mathrm{Fe}(\mu \mathrm{M}), \mathrm{Mn}, \mathrm{Zn}, \mathrm{Cu}, \mathrm{Pb}$ and $\mathrm{Cd}(\mathrm{nM})$ in the reference materials in SLEW-3 (estuarine water), CASS-4 (nearshore seawater) and SLRS-4 (river water); number of replicates in brackets.

\begin{tabular}{clcccccc}
\hline Values & $\begin{array}{c}\mathbf{F e} \\
(\mu \mathrm{M})\end{array}$ & $\begin{array}{c}\mathbf{M n} \\
(\mathrm{nM})\end{array}$ & $\begin{array}{c}\mathbf{Z n} \\
(\mathrm{nM})\end{array}$ & $\begin{array}{c}\mathbf{C u} \\
(\mathrm{nM})\end{array}$ & $\begin{array}{c}\mathbf{P b} \\
(\mathrm{nM})\end{array}$ & $\begin{array}{c}\mathbf{C d} \\
(\mathrm{nM})\end{array}$ \\
\hline \multirow{2}{*}{ SLEW-3 } & Obtained & & & $\begin{array}{c}2.72 \pm 1.18 \\
(\mathrm{n}=3)\end{array}$ & $\begin{array}{c}27.0 \pm 0.07 \\
(\mathrm{n}=3)\end{array}$ & & $\begin{array}{c}0.386 \pm 0.07 \\
(\mathrm{n}=3)\end{array}$ \\
& Certified & & & $3.07 \pm 0.57$ & $24.39 \pm 1.89$ & & $0.427 \pm 0.036$ \\
\hline \multirow{2}{*}{ CASS-4 } & Obtained & & & $\begin{array}{c}5.8 \pm 1.0 \\
(\mathrm{n}=13)\end{array}$ & $\begin{array}{c}9.4 \pm 0.5 \\
(\mathrm{n}=6)\end{array}$ & $\begin{array}{c}0.068 \pm 0.012 \\
(\mathrm{n}=13)\end{array}$ & $\begin{array}{c}0.236 \pm 0.033 \\
(\mathrm{n}=13)\end{array}$ \\
& Certified & & & $5.8 \pm 0.9$ & $9.3 \pm 0.8$ & $0.047 \pm 0.017$ & $0.231 \pm 0.027$ \\
\hline \multirow{2}{*}{ SLRS-4 } & Obtained & $\begin{array}{c}0.23 \pm 0.02 \\
(\mathrm{n}=5)\end{array}$ & $\begin{array}{c}63.5 \pm 2.3 \\
(\mathrm{n}=5)\end{array}$ & & & & \\
& Certified & $0.18 \pm 0.09$ & $61.3 \pm 3.3$ & & & & \\
\hline
\end{tabular}




\section{ACCEPTED MANUSCRIPT}

Table 2 - Concentrations and standard deviation of Fe (\%), Mn, Zn, Cu, Pb and $\mathrm{Cd}\left(\mu \mathrm{g} \mathrm{g}^{-1}\right)$ in sediment solids colonised by Spartina maritima and Sarcocornia fruticosa from Rosario salt marsh. Probability (p) was provided by Kruskal-Wallis test considering the data of all depths.

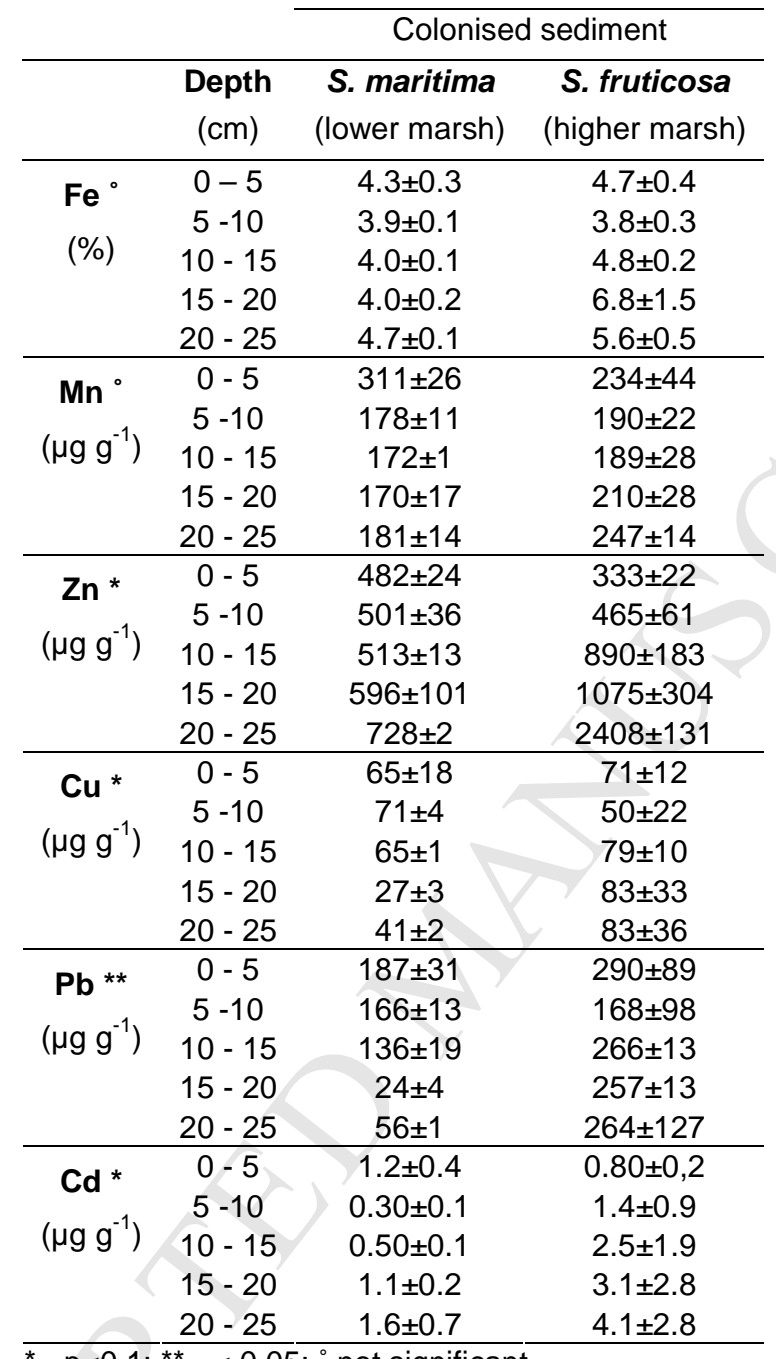

$\bar{\star}-\mathrm{p}<0.1 ;{ }^{\star \star}-<0.05 ;{ }^{\circ}$ not significant 


\section{ACCEPTED MANUSCRIPT}

Table 3 - Dry weight belowground biomass $\left(\mathrm{g} \mathrm{m}^{-2}\right)$, concentrations and standard deviation of Fe (\%), Mn, $\mathrm{Zn}, \mathrm{Cu}, \mathrm{Pb}$ and $\mathrm{Cd}\left(\mathrm{\mu g} \mathrm{g}^{-1}\right)$ in belowground biomass of Spartina maritima and Sarcocornia fruticosa from Rosario salt marsh. Probability $(p)$ was provided by Kruskal-Wallis test considering the data of all depths. Roots were inexistent in 20-25-cm layer.

\begin{tabular}{|c|c|c|c|}
\hline & \multirow[b]{2}{*}{$\begin{array}{c}\text { Depth } \\
(\mathrm{cm})\end{array}$} & \multicolumn{2}{|c|}{ Belowground biomass } \\
\hline & & $\begin{array}{l}\text { S. maritima } \\
\text { (lower marsh) }\end{array}$ & $\begin{array}{c}\text { S. fruticosa } \\
\text { (higher marsh) }\end{array}$ \\
\hline \multirow{5}{*}{$\begin{array}{c}\text { Biomass ** } \\
\qquad\left(\mathrm{g} \mathrm{m}^{-2}\right)\end{array}$} & $0-5$ & 282 & 1001 \\
\hline & $5-10$ & 425 & 1058 \\
\hline & $10-15$ & 346 & 641 \\
\hline & $15-20$ & 238 & 829 \\
\hline & $20-25$ & - & 344 \\
\hline \multirow{5}{*}{$\begin{array}{l}\mathrm{Fe}^{\circ} \\
(\%)\end{array}$} & $0-5$ & $2.8 \pm 0.5$ & $3.3 \pm 0.3$ \\
\hline & $5-10$ & $9.8 \pm 4.2$ & $1.7 \pm 0.1$ \\
\hline & $10-15$ & $4.4 \pm 0.7$ & $4.4 \pm 0.3$ \\
\hline & $15-20$ & $4.5 \pm 0.2$ & $6.0 \pm 1.0$ \\
\hline & $20-25$ & - & $5.2 \pm 0.6$ \\
\hline \multirow{5}{*}{$\begin{array}{c}\mathbf{M n}^{\circ} \\
\left(\mu \mathrm{g} \mathrm{g}^{-1}\right)\end{array}$} & $0-5$ & $211 \pm 235$ & $47 \pm 18$ \\
\hline & $5-10$ & $210 \pm 80$ & $44 \pm 5$ \\
\hline & $10-15$ & $99 \pm 10$ & $89 \pm 44$ \\
\hline & $15-20$ & $90 \pm 34$ & $176 \pm 40$ \\
\hline & $20-25$ & - & $190 \pm 9$ \\
\hline \multirow{5}{*}{$\begin{array}{c}\mathbf{Z n}^{\circ} \\
\left(\mu \mathrm{g} \mathrm{g}^{-1}\right)\end{array}$} & $0-5$ & $2923 \pm 1888$ & $576 \pm 156$ \\
\hline & $5-10$ & $2468 \pm 1439$ & $3313 \pm 1355$ \\
\hline & $10-15$ & $2538 \pm 764$ & $5116 \pm 585$ \\
\hline & $15-20$ & $3571 \pm 740$ & $5875 \pm 585$ \\
\hline & $20-25$ & - & $11017 \pm 1693$ \\
\hline \multirow{5}{*}{$\begin{array}{c}\mathbf{C u}^{* \star} \\
\left(\mu \mathrm{g} \mathrm{g}^{-1}\right)\end{array}$} & $0-5$ & $104 \pm 59$ & $227 \pm 123$ \\
\hline & $5-10$ & $149 \pm 73$ & $305 \pm 41$ \\
\hline & $10-15$ & $190 \pm 49$ & $334 \pm 22$ \\
\hline & $15-20$ & $212 \pm 106$ & $293 \pm 3$ \\
\hline & $20-25$ & - & $236 \pm 4$ \\
\hline \multirow{5}{*}{$\mathrm{Pb}^{*}$} & $0-5$ & $522 \pm 218$ & $599 \pm 221$ \\
\hline & $5-10$ & $1528 \pm 243$ & $1196 \pm 398$ \\
\hline & $10-15$ & $1123 \pm 222$ & $2739 \pm 186$ \\
\hline & $15-20$ & $453 \pm 88$ & $2106 \pm 186$ \\
\hline & $20-25$ & - & $2113 \pm 74$ \\
\hline \multirow{5}{*}{$\begin{array}{l}C d^{\star \star} \\
\left(\mu g g^{-1}\right)\end{array}$} & $0-5$ & $19 \pm 14$ & $13 \pm 7$ \\
\hline & $5-10$ & $9 \pm 9$ & $27 \pm 5$ \\
\hline & $10-15$ & $11 \pm 3$ & $23 \pm 2$ \\
\hline & $15-20$ & $17 \pm 3$ & $23 \pm 2$ \\
\hline & $20-25$ & - & $30 \pm 4$ \\
\hline
\end{tabular}

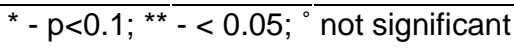




\section{ACCEPTED MANUSCRIPT}

Table 4 - Ranges of temperature, salinity and $\mathrm{Fe}, \mathrm{Mn}, \mathrm{Zn}(\mu \mathrm{M}), \mathrm{Cu}, \mathrm{Pb}$ and $\mathrm{Cd}(\mathrm{nM})$ pore water concentrations in sediments $(0-25 \mathrm{~cm})$ at the air exposure situation $(\mathrm{t}=0)$, colonised Spartina maritima and Sarcocornia fruticosa from Rosario salt marsh. Probability $(p)$ was provided by Kruskal-Wallis test considering the data of all depths.

\begin{tabular}{cccc} 
& & \multicolumn{2}{c}{ Pore waters } \\
\cline { 3 - 4 } & & $\begin{array}{c}\text { S. maritima } \\
\text { (lower marsh) }\end{array}$ & $\begin{array}{c}\text { S. fruticosa } \\
\text { (higher marsh) }\end{array}$ \\
\hline $\begin{array}{c}\text { Temperature } \\
\text { Salinity }\end{array}$ & ${ }^{\circ} \mathrm{C}$ & $14-15$ & $14-15$ \\
$\mathrm{Fe}^{\circ}$ & & $32.4-33.6$ & $28.5-31.8$ \\
$\mathrm{Mn}^{\circ}$ & $\mu \mathrm{M}$ & $0.32-13$ & $0.17-65$ \\
$\mathrm{Zn}^{* *}$ & & $0.1-34$ & $5.8-14$ \\
$\mathrm{Cu}^{* *}$ & & $0.99-28$ & $27-201$ \\
$\mathrm{~Pb}{ }^{* *}$ & $\mathrm{nM}$ & $1.0-15$ & $29-268$ \\
$\mathrm{Cd}^{* *}$ & & $0.10-1.4$ & $0.27-75$ \\
\hline${ }^{* *}-\mathrm{p}<0.05 ;{ }^{\circ}$ & not significant &
\end{tabular}




\section{ACCEPTED MANUSCRIPT}

Table 5 - Estimated diffusive fluxes and advective transport of $\mathrm{Fe}, \mathrm{Mn}, \mathrm{Zn}, \mathrm{Cu}, \mathrm{Pb}$ and $\mathrm{Cd}$ in Rosário sediments colonised Spartina maritima and Sarcocornia fruticosa from Rosario salt marsh. Positive fluxes indicate net exportation of metals from the sediment to the overlying waters.

\begin{tabular}{cccc}
\hline \multicolumn{2}{c}{$\begin{array}{c}\text { Diffusive flux } \\
\left(\mathrm{nmol} \mathrm{m}^{-2} \mathrm{~d}^{-1}\right)\end{array}$} & \multicolumn{2}{c}{$\begin{array}{c}\text { Advective flux } \\
\left(10^{3} \times \mathrm{nmol} \mathrm{m}^{-2} \mathrm{~d}^{-1}\right)\end{array}$} \\
\hline $\begin{array}{c}\text { S. } \text { maritima } \\
\text { (lower marsh) }\end{array}$ & $\begin{array}{c}\text { S. fruticosa } \\
\text { (upper marsh) }\end{array}$ & $\begin{array}{c}\text { S. maritima } \\
\text { (lower marsh) }\end{array}$ & $\begin{array}{c}\text { S. fruticosa } \\
\text { (upper marsh) }\end{array}$ \\
\hline 105 & -510 & 9520 & 1640 \\
4800 & 290 & 24 & -17 \\
-140 & 570 & 220 & 82 \\
-17 & 27 & 74 & 16 \\
0.4 & -4.0 & 13 & 15 \\
0.04 & 3.0 & 0.3 & 0.08 \\
\hline
\end{tabular}


FIGURE CAPTIONS

Figure 1 - Location of the Rosario salt marsh in the Tagus estuary.

Figure 2 - Depth metal concentrations in pore waters of sediments at air-exposed conditions $(t=0), 5,10$ and 50 minutes after the tidal flooding of the lower marsh colonised by $S$. maritima. Standard deviation bars of the three replicates are included.

Figure 3 - Depth metal concentrations in pore waters of sediments at air-exposed conditions $(t=0), 5,10$ and 50 minutes after the tidal flooding of the higher marsh colonised by $S$. fruticosa. Standard deviation bars of the three replicates are included.

Figure 4 - Time course evolution of $\mathrm{Fe}, \mathrm{Mn}, \mathrm{Zn}, \mathrm{Cu}, \mathrm{Pb}$ and $\mathrm{Cd}$ concentrations in the dissolved fraction of flooding water in the areas colonised by S. fruticosa and S. maritima of the Rosario marsh. Standard deviation bars of the three replicates are included. 


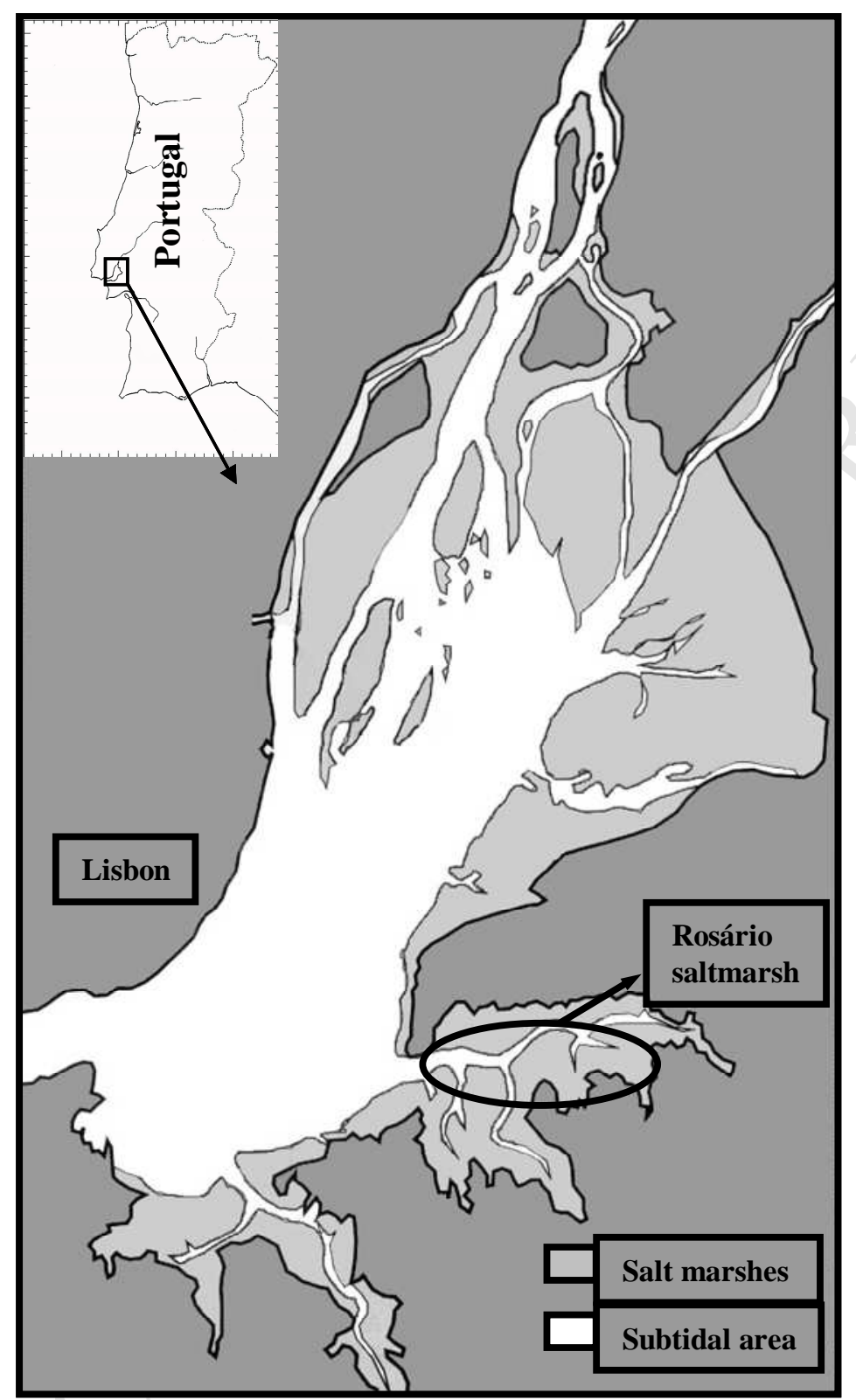

Figure 1 

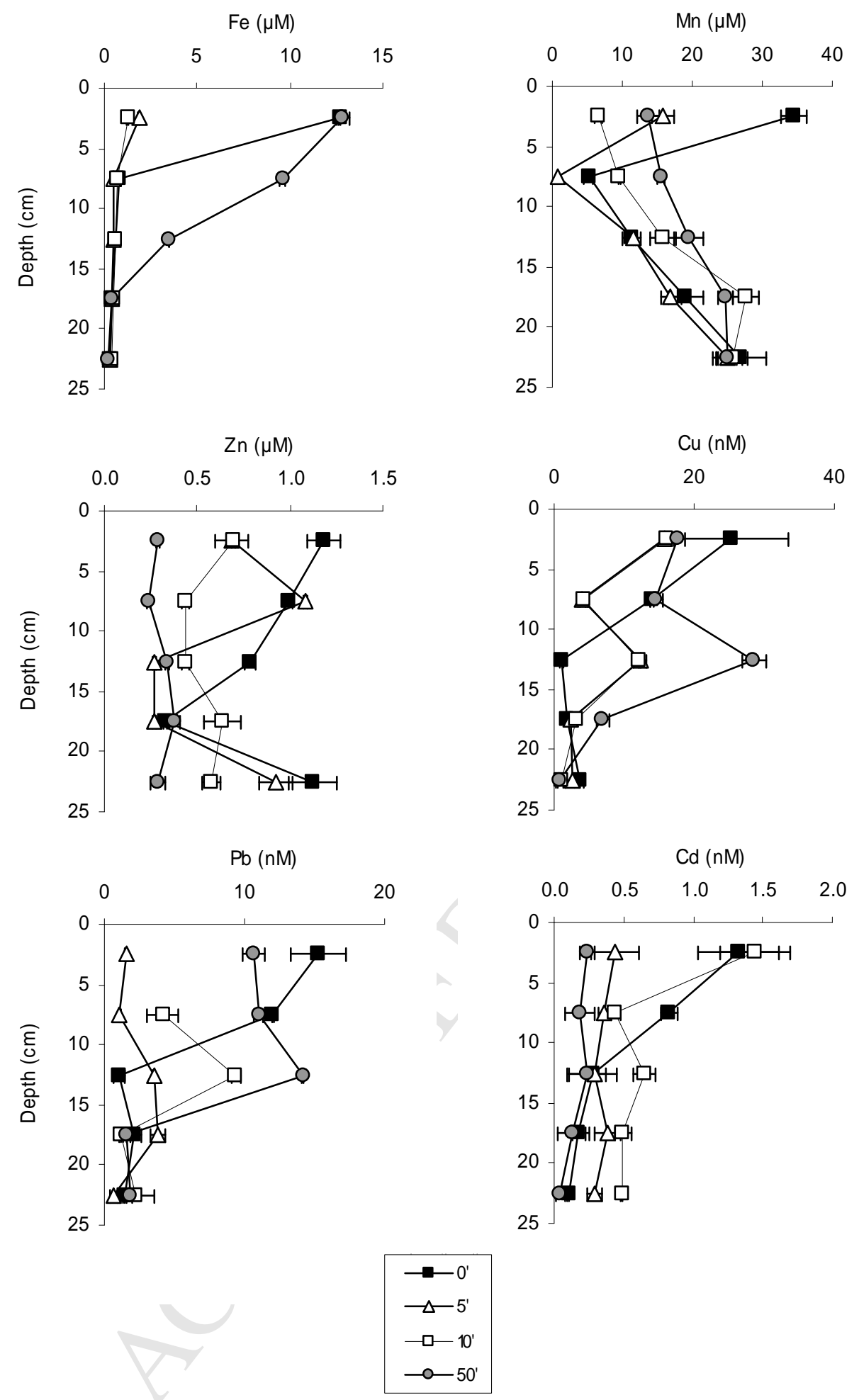

Figure 2 
$\mathrm{Fe}(\mu \mathrm{M})$
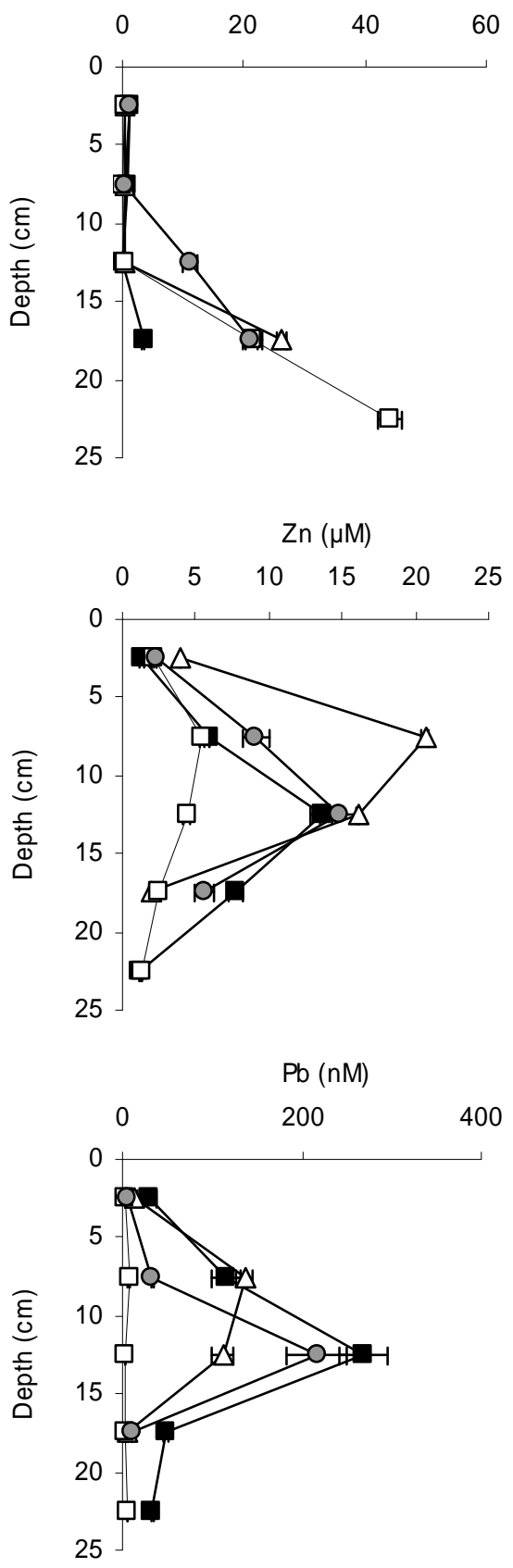

$\mathrm{Mn}(\mu \mathrm{M})$

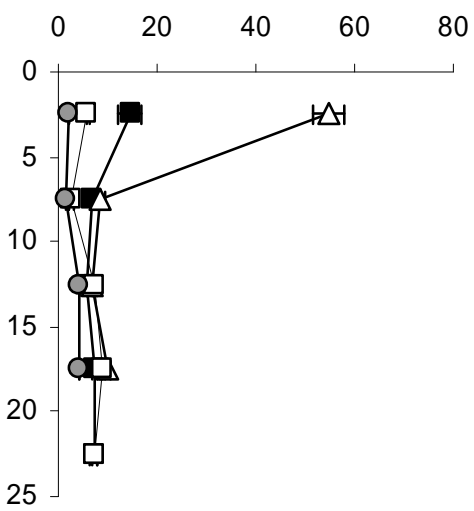

$\mathrm{Cu}$ (nM)

$\begin{array}{llllll}0 & 50 & 100 & 150 & 200 & 250\end{array}$
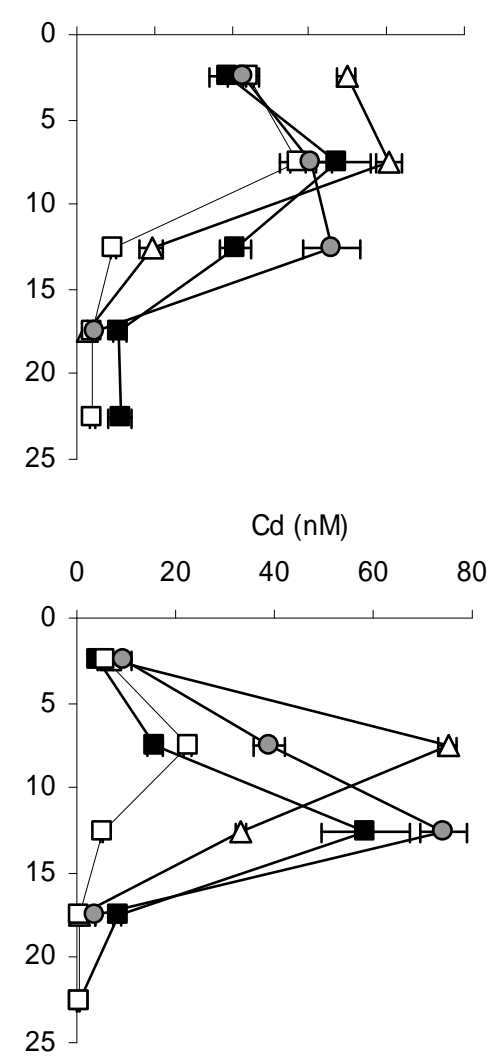

$\longrightarrow 0^{\prime}$
$\triangle-5^{\prime}$
$\square-10^{\prime}$
$\multimap-50^{\prime}$

Figure 3 

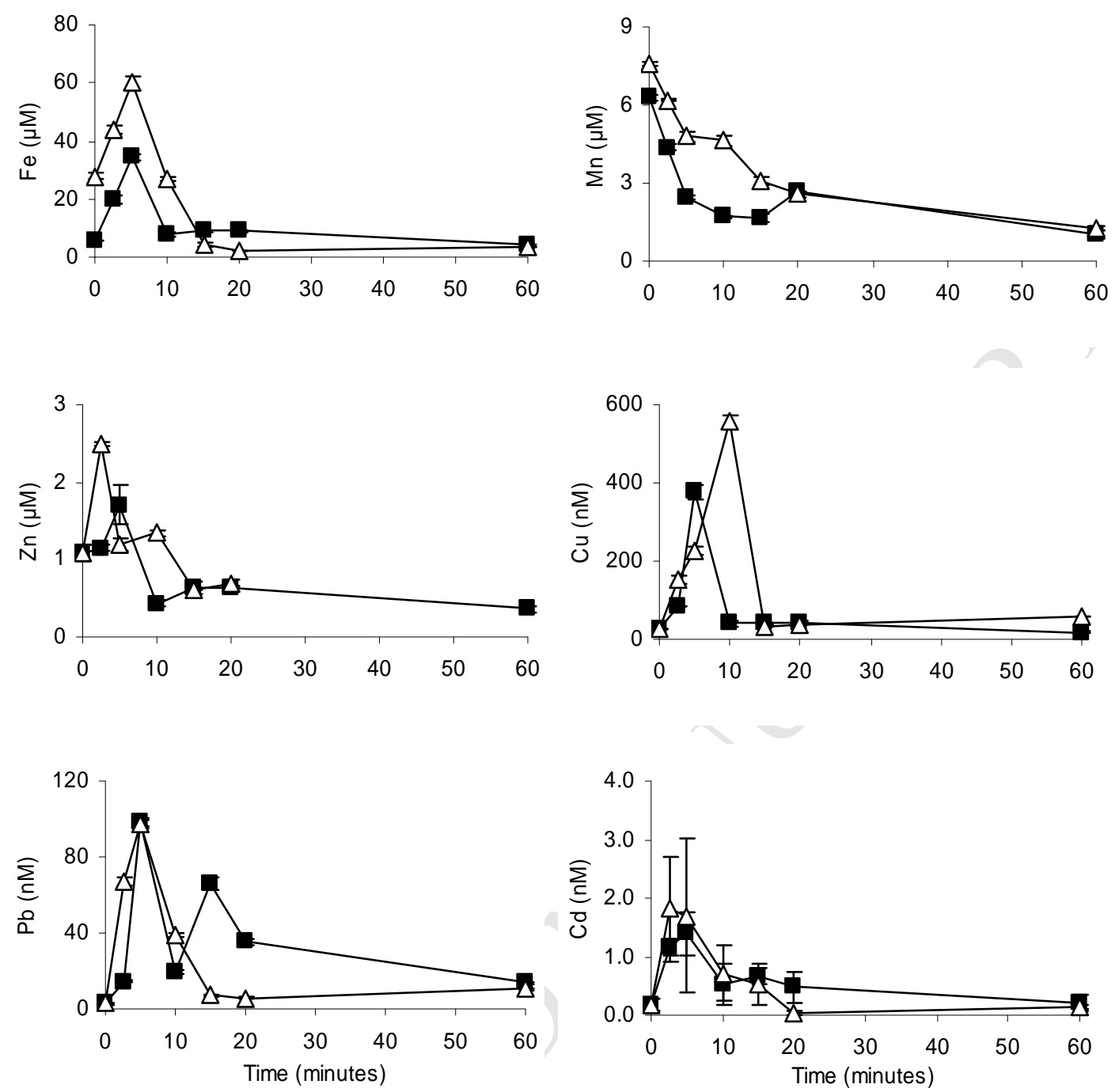

$\rightarrow-S$. fruticosa

$\neg$ S. maritima

Figure 4 